\section{Characterization and speculations on the urbanization of visceral leishmaniasis in Brazil}

\author{
Caracterização e especulações acerca da \\ urbanização da leishmaniose visceral no Brasil
}

Carlos Henrique Nery Costa 1

American visceral leishmaniasis was first recognized in 1913 1. It was a typically rural disease. Origins of the disease are controversial, but given the genetic identity with Leishmania infantum and their ecological identity (since both are transmitted to canids) some authors believe the disease came from the Old World 2 . Due to the fact that the disease is frequently found in fox and opossum in the Americas, other authors believe it originated on the American continent 3 . This controversy has implications for urban visceral leishmaniasis, given that if it were indeed an exotic disease imported to dogs during the colonial period and that secondarily penetrated the wild environment, transmission could be interrupted by controlling the canine enzootic. This idea favors control of the disease by culling dogs. Unfortunately, hope that the disease can be eradicated has waned after three major intervention trials failed to demonstrate any certainty concerning the impact of this strategy on transmission to humans or even to dogs $4,5,6$.

The year 1981 witnessed the beginning of urbanization of visceral leishmaniasis in Brazil, in Teresina, capital of the State of Piauí, where 55 cases were reported, far more than the occasional reports of imported cases over the years 7 . In the following year, the urbanization process appeared in São Luís (Maranhão) and Montes Claros (Minas Gerais), later spreading to various other large cities. Before 1980, nearly all the patients were from rural areas or villages with typical 
landscapes (foothills, hollows, or river valleys) 8 , although some cases of visceral leishmaniasis had already been reported in smaller towns since the 1950s and even in somewhat larger cities like Sobral and Aracati in Ceará State, Jacobina in Bahia, and Santarém in Pará.

In the 1980s, four new and uncommon events occurred. First, transmission of the disease in fully urbanized areas in larger cities. Second, rapid spread in the Northeast and to various cities in the North, Central-West, and Southeast. After the outbreaks in Teresina/Timon (Maranhão) and the island of São Luís (Maranhão) 9, epidemics occurred in the following order in these cities: Natal (Rio Grande do Norte) 10, Belo Horizonte 11 and Montes Claros (Minas Gerais), Corumbá and Campo Grande (Mato Grosso do Sul), Aracaju (Sergipe), Caxias and Imperatriz (Maranhão), Jequié (Bahia), Araçatuba and Bauru (São Paulo), Várzea Grande (Mato Grosso), Palmas (Tocantins), and now Fortaleza (Ceará), Brasilia (Federal District), and Piracicaba (São Paulo), among others 12 , all cities with more than one hundred thousand inhabitants, in addition to a myriad of smaller towns. Third, there was a large proportion of urban versus rural cases. The fourth event was the emergence of large-scale urban epidemics with ten-year cycles 13 . These four characteristics in the distribution of visceral leishmaniasis demonstrate that there was a new large-scale epidemiological event under way, since urbanization changed the eco-epidemiological features of the disease and had a significant impact on the distribution of its related morbidity and mortality in Brazil, with significant health and medical consequences. Between 200 and 300 Brazilians now die of visceral leishmaniasis every year.

One of the changes was in case-fatality, as occurred in Araçatuba and Belo Horizonte, since the rate tends to be higher when transmission occurs for the first time, given that visceral leishmaniasis confers lasting immunity (and creates herd immunity). The force of transmission is thus inversely proportional to age. Therefore, when the population is not immune, patients are older on average, and since the disease is more severe in older individuals, the case-fatality rate in recently affected cities is higher. Additionally, since case-fatality in very small children is also high 14,15 when transmission is very intense in cities that have experienced the disease longer, casefatality can also increase. However, historical mortality series are needed for further clarification of this issue.

At least three cities have conducted studies on the spatial characteristics of visceral leishmaniasis in the urban setting. Research in Jequié did not show either an urban pattern associated with canine visceral leishmaniasis or characteristic clusters of canine infection cases 16 . In Belo Horizonte, cases of human and canine visceral leishmaniasis were clustered, but no typically urban feature was defined 17 except for altitude 18 .

In Teresina, cases were clustered on the urban periphery in areas bordering on green forest areas or pastures; the latter appeared as independent risk factors in relation to type of housing, crowding, and socioeconomic status 19. Houses with more residents located in areas with higher incidence of the disease were also at increased risk 20 . While the type of housing construction and water supply were not related to incidence, lack of sewerage or regular garbage collection were associated with increased incidence. Finally, a multilevel analysis showed that socioeconomic status (poverty) and increased vegetation were associated with higher incidence of the disease in humans and amplified the association with canine infection before and during the human epidemic 21 .

This observation of an association with periurban green areas indicates that the urban transmission cycles depend on a relationship with the sylvatic environment. There are two reasons for this dependence: (1) a simple increase in the degree of contact between sources of infection and susceptible individuals mediated by increased exposure to the vector Lutzomyia longipalpis on the periurban outskirts and (2) the suggested existence of a sylvatic transmission cycle linked to the urban peripheries through wild mammals, namely $L$. chagasi reservoirs inhabiting the vicinity of urban areas, like fox and opossum. In fact, we recently described the presence of high levels of antibodies against $L u$. longipalpis saliva in fox specimens from the periphery of Teresina with evidence of natural infection 22 .

Thus, the scenario for the dynamics of urban visceral leishmaniasis transmission appears to be that of a sylvatic disease among fox, transmitted on the urban peripheries to dogs, which in turn apparently amplify and transmit it to humans living in marginal areas, under poor socioeconomic conditions with precarious urban services. However, this pattern does not rule out transmission under better socioeconomic conditions in central areas of cities, as occurs in Teresina and Belo Horizonte, or occasionally among humans 7,17.

At any rate, these conclusions are limited by the lack of knowledge with more robust evidence, since not even the role of dogs has been clearly established. On the one hand, while prior or current spatial correlation between canine seroprevalence and the incidence of human visceral leishmaniasis 18,21 may indicate that the human disease depends on canine infection, it may also 
merely show that both human and canine infection result from a common source. This would reemphasize the concept of urban dependence on sylvatic transmission cycles of $L$. chagasi.

A socioeconomic approach has dominated the explanation for the urbanization of visceral leishmaniasis. It has been speculated that drought in endemic regions has facilitated epidemics by leading to the emigration of humans and infected dogs to cities, subject to deforestation and degraded living conditions 7 . This is an attractive hypothesis, because it is also supported by the observation that the highest incidence in cities occurs on the urban outskirts and in poor neighborhoods, where most rural migrants concentrate.

However, this explanation failed to stand up over time. For example, visceral leishmaniasis succeeded in entering cities like Araçatuba and Campo Grande that had not undergone rapid and chaotic urban growth and were not surrounded by slums, and where the epidemics were not limited to the periphery. Neither was there an exceptionally intense migratory flow concurrent with the beginning of the epidemic in these cities, as occurred in Teresina and São Luís, where the epidemics were preceded by regional droughts and rapid spread of slums. It its also necessary to explain why cities that experienced a strong migratory flow from endemic rural areas, like Recife (Pernambuco) and Salvador (Bahia), were not hit by epidemics.

Thus, the hypotheses or explanations presented thus far in relation to the urbanization process fail to elucidate the entire phenomenon and are therefore insufficient. New explanations are needed for the urbanization of $L u$. longipalpis and ease of transmission. For example, changes in the ecology and biology of Lu. longipalpis could explain all the urban epidemiological features.

Ecological changes with attractive biological repercussions would be those that explained the invasion of cities by $L u$. longipalpis and increased the vector's capacity to transmit $L$. chagasi. Sand flies have quite eclectic eating habits, such that they seek to circulate between animal shelters and human dwellings, between the peridomicile and the sylvatic environment. The females are non-autogenous and require blood meals for oviposition and to complete the life cycle 23 . They only require feeding on blood a few times in their lives, and thus, like males, use plant sap and nectar as their main sources of energy and water 24 . The existence of a plant that particularly attracts Lu. longipalpis or that somehow provides protection against predators could explain the vector's proliferation in areas where this plant were abun- dant. In addition, it would have to be found in the urban context, particularly in cities affected by visceral leishmaniasis epidemics. Plant species that could meet these characteristics are the acacias. Importantly, the visceral leishmaniasis epidemic that devastated Sudanese populations in the 1980s and 90s occurred in acacia forests 25 , and the species Acacia podalyriifolia (Mt. Morgan wattle or Queensland silver wattle) is widespread in Brazilian cities and is recommended by landscapers for urban tree-planting 26 .

Together with the vectorial mortality rate, another element that determines changes in vectorial competence is the duration of the extrinsic incubation period. This period includes the time ranging from the vector's infective bite until the arrival of metacyclic promastigotes in the proboscis. Transmission thus depends on the probability of survival until the end of the extrinsic incubation period, which has an exponential repercussion on the number of secondary events in relation to each index case, the so-called basic reproduction number for infection $\left(\mathrm{R}_{0}\right) 27$. Plant sugars appear to modify the sand flies' success in transmitting Leishmania 28 . If, besides providing attractive food or protection for $L u$. longipalpis, the sap or nectar of acacias or other plants were capable of shortening the extrinsic incubation period of L. chagasi, the resulting exponential increase in $\mathrm{R}_{0}$ would provide an additional explanation for the occurrence of urban epidemics.

Genetic changes in Lu. longipalpis populations may have the same impact as ecological alterations. Candidate molecules that present gene polymorphisms with repercussions on L. chagasi transmission would be those that influence the protozoan's development in the vector's digestive tract. Lipophosphoglycan (LPG) is a Leishmania surface glycoconjugate that participates in adhesion to the intestinal wall 29. If populations of $\mathrm{Lu}$. longipalpis associated with urban epidemics have evolved with polymorphisms in the LPG ligand gene so as to allow rapid and efficient development of $L$. chagasi, the epidemics would be explained. The only flaw is not explaining the spread of $\mathrm{Lu}$. longipalpis to areas where it did not exist before. This would require the polymorphism to result in some adaptive advantage.

Unfortunately, measures to control L. chagasi transmission have not shown satisfactory results, and programs to cull seroreactive dogs 4,5 and non-controlled trials using modern insecticides have proven ineffective 14 . The only measure that reduced transmission was a trial with DDT 50 years ago in rural areas of Ceará State 30 . This trial at least illustrates that although dog-culling programs have apparently failed, there could be 
some hope for visceral leishmaniasis control using insecticides in crisis situations, such as at the beginning of urban epidemics. In addition, evidence is needed to incriminate poor conditions in urban services, and to show that investments to improve basic sanitation could have an impact on distribution of the disease in cities.

Key knowledge is still lacking, and certain research lines need to be prioritized to fill this gap. Research on the role of dogs in amplifying transmission of the disease in cities is particularly pressing. Insecticide trials are important to assess whether new insecticides can have an impact similar to that obtained with DDT. The investigation into ecological or molecular determinants that participate in L. chagasi transmission merits specific attention. Efforts with public investments should be made to develop vaccines for humans, since a viable vaccine appears to be within reach, given that few vaccinated individuals become ill when infected 31 . Even modest vaccine results could substantially reduce the impact of this disease, which in the last quarter century has challenged and defeated both the scientific community and the public health field around the world.

\section{Resumo}

As hipóteses ou explicações apresentadas até o momento para o processo de urbanização da leishmaniose visceral americana são insatisfatórias. Uma hipótese alternativa é a de que mudanças na ecologia e biologia do vetor, Lutzomyia longipalpis, poderiam explicar as feições epidemiológicas urbanas da doença. De forma a suprir lacunas no conhecimento sobre esse processo de urbanização, destacam-se algumas linhas de pesquisa prioritárias: a investigação do papel de cães na amplificação da transmissão da doença nas cidades, ensaios de campo com novos inseticidas, investigação dos determinantes ecológicos ou moleculares que participam da transmissão de Leishmania chagasi. Esforços com investimentos públicos devem ser feitos para o desenvolvimento de vacinas para humanos, pois uma vacina não parece estar tão distante. Resultados vacinais mesmo modestos podem reduzir substancialmente o impacto dessa doença que, no último quarto de século, desafiou e venceu a ciência e a saúde pública mundo afora.

Leishmaniose Visceral; Urbanização; Vacinas

\section{References}

1. Alencar JE. Aspectos clínicos do calazar americano. Rev Bras Malariol Doenças Trop 1959; 11:19-44.

2. Ochsenreither S, Kuhls K, Schaar M, Presber W, Schönian G. Multilocus microsatellite typing as a new tool for discrimination of Leishmania infantum MON-1 strains. J Clin Microbiol 2006; 44:495-503.

3. Lainson R. The American leishmaniases: some observations on their ecology and epidemiology. Trans R Soc Trop Med Hyg 1983; 77:569-96.

4. Ashford DA, David JR, Freire M, David R, Sherlock I, Eulálio MC, et al. Studies on control of visceral leishmaniasis: impact of dog control on canine and human visceral leishmaniasis in Jacobina, Bahia, Brazil. Am J Trop Med Hyg 1998; 59:53-7.

5. Dietze R, Barros GB, Teixeira L, Harris J, Michelson K, Falqueto A, et al. Effect of eliminating seropositive canines on the transmission of visceral leishmaniasis in Brazil. Clin Infect Dis 1997; 25:1240-2.

6. Moreira Jr. ED, Mendes-de-Souza VM, Sreenivasan M, Nascimento EG, Pontes-de-Carvalho L. Assessment of an optimized dog-culling program in the dynamics of canine Leishmania transmission. Vet Parasitol 2004; 122:245-52. 
7. Costa CH, Pereira HF, Araújo MV. Epidemia de leishmaniose visceral no Estado do Piauí, Brasil 1980-1986. Rev Saúde Pública 1990; 24:361-72.

8. Deane LM, Deane MP. Visceral leishmaniasis in Brazil: geographical distribution and transmission. Rev Inst Med Trop São Paulo 1962; 4:198-212.

9. Costa JML, Viana GMC, Saldanha ACR, Nascimento MDSB, Alvim AC, Burattini MN, et al. Leishmaniose visceral no Estado do Maranhão, Brasil. A evolução de uma epidemia. Cad Saúde Pública 1995; 11:321-4.

10. Jeronimo SM, Oliveira RM, Mckay S, Costa RM, Sweet J, Nascimento ET, et al. An urban outbreak of visceral leishmaniasis in Natal, Brazil. Trans R Soc Trop Med Hyg 1994; 88:386-8.

11. Silva ES, Gontijo CMF, Pacheco RS, Fiuza VOP, Brazil RP. Visceral leishmaniasis in the metropolitan Region of Belo Horizonte, State of Minas Gerais, Brazil. Mem Inst Oswaldo Cruz 2001; 96:285-91.

12. Ministério da Saúde. Tópicos de saúde: leishmaniose visceral. http://portal.saude.gov.br/portal/ saude/visualizar_texto.cfm?idtxt=22141 (accessed on 01/May/2007).

13. Sherlock IA. Ecological interactions of visceral leishmaniasis in the State of Bahia, Brazil. Mem Inst Oswaldo Cruz 1996; 91:671-83.

14. Camargo-Neves VLF. A leishmaniose visceral americana no Estado de São Paulo: situação atual. Boletim Epidemiológico Paulista 2004, 1:1-4.

15. Seaman J, Mercer AJ, Sondorp HE, Herwaldt BL. Epidemic visceral leishmaniasis in southern $\mathrm{Su}$ dan: treatment of severely debilitated patients under wartime conditions and with limited resources. Ann Intern Med 1996; 124:664-72.

16. Paranhos-Silva M, Nascimento EG, Melro MC, Oliveira GG, Santos WL, Pontes-de-Carvalho LC, et al. Cohort study on canine emigration and Leishmania infection in an endemic area for American visceral leishmaniasis. Implications for the disease control. Acta Trop 1998; 69:75-83.

17. Oliveira CL, Assunção RM, Reis IA, Proietti FA. Spatial distribution of human and canine visceral leishmaniasis in Belo Horizonte, Minas Gerais State, Brasil, 1994-1997. Cad Saúde Pública 2001; 17:1231-9.

18. Margonari C, Freitas CR, Ribeiro RC, Moura ACM, Timbó M, Gripp AH, et al. Epidemiology of visceral leishmaniasis through spatial analysis, in Belo Horizonte municipality, state of Minas Gerais, Brazil. Mem Inst Oswaldo Cruz 2006; 101:31-8.

19. Werneck GL, Costa CHN, Walker AM, David JR, Wand M, Maguire JH. The urban spread of visceral leishmaniasis: clues from spatial analysis. Epidemiology 2002; 13:364-7.
20. Costa CHN, Werneck GL, Rodrigues Jr. L, Santos MV, Araújo IB, Moura LS, et al. Household structure and urban services: neglected targets in the control of visceral leishmaniasis. Ann Trop Med Parasitol 2005; 99:229-36.

21. Werneck GL, Costa CHN, Walker AM, David JR, Wand M, Maguire JH. Multilevel modeling of the incidence of visceral leishmaniasis in Teresina, Brazil. Epidemiol Infect 2007; 135:195-201.

22. Gomes RB, Mendonça IL, Silva VC, Ruas J, Silva MB, Cruz MS, et al. Antibodies against Lutzomyia longipalpis saliva in the fox Cerdocyon thous and the sylvatic cycle of Leishmania chagasi. Trans R Soc Trop Med Hyg 2007; 101:127-33.

23. Benkova I, Volf P. Effect of temperature on metabolism of Phlebotomus papatasi (Diptera:Psychodidae). J Med Entomol 2007; 44:150-4.

24. Schlein Y, Jacobson RL, Müller GC. Sand fly feeding on noxious plants: a potential method for the control of leishmaniasis. Am J Trop Med Hyg 2001; 65:300-3.

25. Elnaiem DEA, Mukhawi AM, Hassan MM, Osman ME, Osman OF, Abdeen MS, et al. Factors affecting variations in exposure to infections by Leishmania donovani in eastern Sudan. East Mediterr Health J 2003; 9:827-36.

26. Yamamoto MA, Schimidt ROL, Couto HTZ, Silva Filho DF. Árvores urbanas. Piracicaba: Prefeitura Municipal de Piracicaba; 2004.

27. Rogers DJ. The dynamics of vector-transmitted diseases in human communities. Philos Trans $\mathrm{R}$ Soc Lond B Biol Sci 1988; 321:513-39.

28. Schlein Y, Jacobson RL. Linkage between susceptibility of Phlebotomus papatasi to Leishmania major and hunger tolerance. Parasitology 2002; 125:343-8.

29. Pimenta PFP, Saraiva EMB, Rowton E, Modi GB, Garraway LA, Beverley SM, et al. Evidence that the vectorial competence of phlebotomine sand flies for different species of Leishmania is controlled by structural polymorphisms in the surface lipophosphoglycan. Proc Natl Acad Sci U S A 1994; 91:9155-9.

30. Deane LM. Epidemiologia e profilaxia de leishmaniose visceral no Brasil. Rev Bras Malariol Doenças Trop 1958; 10:431-50.

31. Werneck GL, Rodrigues L, Santos MV, Araújo IB, Moura LS, Lima SS, et al. The burden of Leishmania chagasi infection during an urban outbreak of visceral leishmaniasis in Brazil. Acta Trop 2002; 83:13-8.

Submitted on 06/Mar/2008

Approved on 10/Mar/2008 